\title{
The Offspring Absence Factor Divorce Runs in the Family (Case Study at the Religious Court Medan in 2020)
}

DOI: https://doi.org/10.47175/rissj.v2i1.180

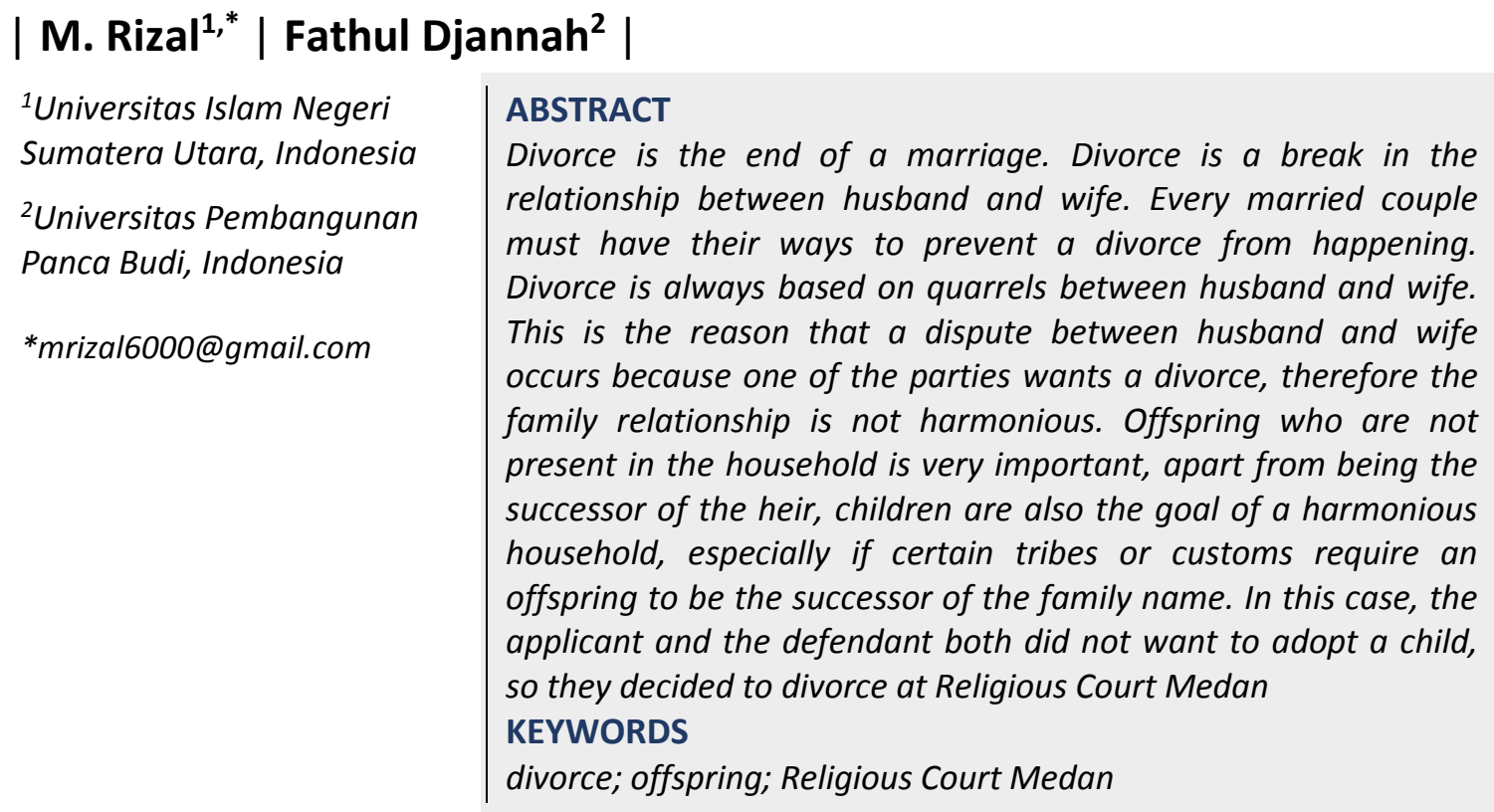

\section{INTRODUCTION}

Marriage is a physical and mental bond between a man and a woman as husband and wife to form a happy and eternal family (household) based on the Supreme Lordship. Such is the provision of Article 1 of Law 1 of 1974 concerning Marriage. Law 1 of 1974 concerning Marriage has the consideration that under the Pancasila philosophy and the aspirations for the development of national law, there is a need for a Law on Marriage that applies to all citizens.

Marriage problems are intended to create a husband and wife's life that is Sakinnah Mawaddah and Warahma. Divorce is part of the dynamic of the household, divorce exists because of marriage. Although the purpose of marriage is not divorce, with different causes or problems.

Marriage is worship as one of the pillars of Islam, so carrying out marriage is something noble in preserving and maintaining the continuity of the household's life which will later produce offspring, although it is not an easy matter to realize. The emergence of changes in the different views of life between husband and wife, the emergence of disagreements between the two, the change in the inclination of the heart in each of them often leads to domestic crises that change the atmosphere of harmony into quarrels, conformity to conflict, affection to hatred, all of which are things that must be faced and resolved. Not a few of the married couples face problems such as the absence of offspring, economic factors and so on.

Divorce is the end of a marriage. Divorce is a break in the relationship between husband and wife, caused by the failure of the husband or wife to carry out their respective roles. 
Divorce is understood as the end of marital instability between husband and wife who then live separately and are legally recognized under the applicable law. ${ }^{1}$

Islam opens a way out of crises or difficulties in the household that cannot be overcome anymore. The way out is made possible by divorce, either through a divorce, khuluk (letting go), and so on. Divorce as a way out must not be taken except in a forced or emergency. ${ }^{2}$ Based on data in the Medan Religious Court from the factors mentioned above, the hereditary factor is probably the least likely to occur because many married couples have taken the path of adopting children as their adopted children (adopted children) with the aim of perfect household integrity. In this case, the husband and wife who feel both physically and mentally healthy, who really want to have offspring from their flesh and blood, decide to separate.

If a husband or wife can accept each other's circumstances, maybe they will not decide to separate, the length of a marriage is a burden for husband and wife because they do not have children, then what will arise is a sense of indifference to each other, lack of time in togetherness, even the demands of the family that make married couples who have not been blessed with children a dilemma. That is one of the triggers or causes of the desire to separate or divorce.

In-Law Number 1 of 1974 concerning marriage, article 39 paragraph 2 "that to divorce there must be sufficient reasons, namely that the husband and wife will no longer be able to live in harmony as husband and wife". ${ }^{3}$ One of the reasons for divorce listed in Government Regulation No.9 of 1975 concerning the implementation of Law No.1 of 1974 concerning marriage (hereinafter abbreviated to PP No.9 of 1975) is due to leave a spouse without valid reasons within a period of two consecutive years. ${ }^{4}$ What is meant by leaving a partner, in this case, is one without permission or for reasons that do not make sense in married life.

The Religious Court as an institution that facilitates a husband and wife divorce either through a lawsuit or petition, as in article 2 of Law number 3 of 2006 "The Religious Court is one of the implementations of judicial power for people seeking justice who are Muslim regarding certain civil cases regulated in law. -this invite ".

Divorce in a marriage is the last way after peace is sought. Divorce is permissible in Islam but that act is hated by Allah and is angry with him..$^{5}$ But, in society, many divorce either from the absence of heredity, economic factors or from other factors, such as psychological factors, biological factors, views of life, differences in tendencies, and so on.

Based on this background, the writer raises the title about, " The Offspring Absence Factor Divorce Runs in the Family (Case Study at Religious Court Medan in 2020) "

\section{Formulation of the Problem}

Identification of problems are:

1. Research approach This research approach is quantitative because this study is concerned with numbers, namely to determine the number of divorces.

\footnotetext{
${ }^{1}$ Fachrina, Rinaldi Eka Putra "Upaya Pencegahan Perceraian Berbasis Keluarga Luas dan Institusi Lokal dalam Masyarakat Minangkabau di Sumatera Barat, 2013

${ }^{2}$ Djamaan Nur, Fiqih munakahat, (Semarang : Dina Utama Semarang, 1993), p. 130

${ }^{3}$ Law of RI Number 1 Year 1974 Concerning Marriage, (Bandung: Citra Umbara, 2007), p. 16

${ }^{4}$ Government Regulation Number 9 of 1975 Concerning, Implementation of Law Number 1 of 1974 Concerning Marriage, (Bandung: Citra Umbara, 2007), p. 49

${ }^{5}$ M Ali hasan, pedoman hidup berumah tangga dalam Islam, (Jakarta: Siraja Prenada Media Group, 2006), p. 103
} 
2. Type of research The type of research in this thesis is a survey because the researcher goes directly to the Religious Court and analyzes documents related to divorce due to economic factors.

Limitation of problems that will be examined are following the identification of the problems above, are limited to problems related to divorce caused by heredity, what is meant by heredity in this case is that one of the partners is difficult to fertilize from a medical perspective in a divorce case that occurs in the Religious Court Medan in 2020.

Research questions as for the problems under study, the following questions can be made:

1. Factors causing divorce at the Religious Court Medan in 2020?

2. What is the divorce due to the offspring's absence at the Religious Court Medan in 2020 ?

\section{Research Purposes}

The objectives to be achieved in this research are:

1. To find out the factors that cause divorce at the Religious Court Medan in 2020

2. To know the description of divorce due to the offspring absence and the impact of these factors on divorce in Medan, 2020.

This research will be useful in gaining insight for the author and encouraging the birth of future researchers on the same problem.

\section{Framework}

Marriage is an important institution that is protected in Islam, to legalize the relationship between two people of different sex according to Islamic law. With the existence of the marriage, two statuses previously did not exist between the two. Namely the man as the husband and the woman as the wife. With the new status between the two, it automatically creates rights and obligations. The marital relationship creates an obligation to support the husband for his wife and children.

In family matters, offspring (children) is one of the important issues that is considered by Islam so that the purity of blood can be maintained and the continuation of mankind can be continued.

\section{RESEARCH METHODS}

The method used in this research is a descriptive method, which is a method that describes or describes what it is from the research results. This research is quantitative in the form of data on divorce due to the offspring absence at the Religious Court Medan in 2020. Quantitative data is data in the form of numbers as a means of finding information about what we want to know.

\section{RESULTS AND DISCUSSION}

Divorce in the terms of Jurisprudence experts is called "talak" or "furqah". The linguistic meaning of divorce is the breaking of a marriage bond and the end of the marital relationship. ${ }^{6}$ According to the term syara talak is; "Breaking the marital ties and ending the husband and wife relationship." ${ }^{7}$

\footnotetext{
${ }^{6}$ Al-Hamdani, Hukum Perkawinan Islam, (Jakarta: Pustaka Amani, 2002), p. 202

${ }^{7}$ Abdul Rahman Ghozali, Fiqih Munakahat, (Jakarta: Kencana, 2010), pp. 191-192
} 
Divorce is a break in the marital relationship between husband and wife. In Islamic legal terms, divorce is called thalaq, which means letting go or leaving. According to Sayyid Sabiq "Talak means letting go of the marriage bond." A divorce is an act that is lawful but hated by Allah SWT. ${ }^{8}$

Given kinship, customary law is customary law that regulates the personal position of a person as a member of a relative, the position of the child towards parents and vice versa the position of the child towards relatives and vice versa and the issue of child guardianship. The kinship customary law regulates kinship ties, based on blood ties (sekutunan) between marriages and traditional marriages (Hilman Hadikusuma; 2003, p; 201).

In the kinship system of indigenous peoples, the descent is important to continue the lineage (clan) either straight or sideways. In general, offspring have a legal relationship based on blood relations, including between parents and their children. There are also legal consequences related to descent being coupled with the singleness of the ancestor, but the legal consequences are not all the same in all regions. Although the legal consequences associated with single ancestry throughout the region are not the same, in reality, there is one main view that is the same on the issue of heredity throughout the region, namely that descent is an essential and absolute element for a clan, tribe or relative who wants a line. the descendants are not extinct, so there are future generations. ${ }^{9}$

Individuals as descendants (family members) have certain rights and obligations related to their position in the family concerned.

According to Prof. Bushar Muhammad, SH descendants can be:

a. Straight, if someone is a direct descendant of another, for example between father and son; between grandfather, father and son, it is called straight down when the sequence is seen from grandfather, father to child, while it is called straight down when the sequence is seen from a child, father to grandfather.

b. Deviating or branching, if there is a single ancestor between two or more people, for example, the father and mother are the same (sibling), or grandmother and so on (Bushar Muhammad; 2006, page: 4). ${ }^{10}$

That is why many married couples decide to divorce or separate because of several factors that encourage them to make decisions that are not easy to do and live with, including factors from family, environment and so on. However, not a few married couples decided to adopt a child to maintain the integrity of their household.

\section{Factors Causing Divorce at the Religious Court Medan in 2020}

As is well known, divorce is the breakup of a marriage, this is of course because there are factors that cause the breakup of a marriage. Before going further, explain what factors cause divorce. Giving divorce to a wife by the husband must go through a legal court process. Because in this case the religious court is the body that has the authority to handle divorce issues for people who are Muslim. The factors that arise as reasons for a wife to file for divorce or a husband to apply for divorce are used as the basis for judges to examine and consider making decisions under Islamic law. Many factors influence the breakup of marriage until divorce occurs.

With the enactment of laws and regulations, it is hoped that divorce outside the court will no longer occur, or it can be called illegal talak. Be it heredity, economy, communication, domestic violence or being involved in cases of lawlessness and so on.

\footnotetext{
${ }^{8}$ Sayyid Sabiq, Fiqih Sunnah, (Bandung: PT. Al-Maarif, 1993), p. 9

${ }^{9} \mathrm{http} / / /$ staffnew.uny.ac.id/upload/132314547/pendidikan/DIKTAT+HUKUM+ADAT.pdf

${ }^{10}$ Bushar Muhammad (2006), Pokok-pokok Hukum Adat, Jakarta, PT Pradnya Paramita.
} 
Every married couple must have their own ways to prevent divorce from happening. Many reasons can make a married couple divorce, and lately it seems that more and more people are deciding to divorce rather than maintain a marriage, the influence of social media has not escaped being one of the causes of divorce.

According to psychologists who handle many cases of marriage, here are 4 big reasons why most couples decide to divorce. ${ }^{11}$

a. Lack of communication

When neither partner wants to talk, whether it's because of each other's egos, to avoid conflict or to avoid discussing uncomfortable issues, the lack of communication can lead to major misunderstandings with each other. The death of communication will further widen the distance between husband and wife.

b. Always show negative feelings

Holding on to negative feelings is bad, not only physically but mentally. But always putting out negative thoughts and feelings towards your partner will make the atmosphere hot, and arguments will always arise. You and he have their shortcomings and if you only blame each other, the marriage bond will be even more tenuous.

c. Show less affection

Of course you married because you loved her, but neither husband nor wife showed it with actions or words. When a husband or wife lacks affection at home, they will tend to seek respect and affection outside the home. This is what gives rise to thirdperson cases or infidelity.

d. Lack of responsibility

If the husband doesn't feel the need for his wife's presence anymore, he will slowly lose his sense of belonging and responsibility towards his wife. Lack of time together, lack of belonging to each other is what causes many couples do end up avoiding each other.

However, the most important thing in married life is good communication, both between husband and wife and both extended families, to avoid divorce or the factors that cause separation or divorce. But there are also not a few of the triggers for divorce, namely the family itself, many negative inputs or influences from the family which lead to poor communication between husband and wife.

\section{How About Divorce Due to the Offspring Absence of the Religious Court Medan in 2020?}

In principle, husband and wife have the right to terminate the marriage by divorcing based on the applicable divorce law. However, a husband and wife who want to divorce must have certain legal reasons and the divorce must be before a court hearing after the competent court has tried to reconcile but neither parties have succeeded in achieving peace. $^{12}$

The specific legal reasons that are meant are the reasons for divorce as stipulated in Article 19 of Government Regulation Number 9 of 1975 concerning the Implementation of Law Number 1 of 1974 concerning Marriage.

\footnotetext{
${ }^{11}$ https://www.fimela.com/parenting/read/3762822/4-penyebab-utama-per divorce-menurut- psychologist Research conducted by the Department of Psychology at the University of Washington can accurately predict as many as $83 \%$ of couples will divorce because of these factors.

${ }^{12}$ Article 39 of Law Number 1 of 1974 concerning Marriage, State Gazette of the Republic of Indonesia of 1974 Number 1, Supplement to the State Gazette of the Republic of Indonesia Number 3019
} 
The reasons for the prescribed divorce are:

a. One of the parties commits adultery or becomes a drunkard, a prostitute, a gambler, and others who are difficult to cure;

b. One of the parties leaves the other party for 2 (two) consecutive years without the consent of the other party and valid reasons or for other reasons beyond its capabilities;

c. One of the parties is sentenced to 5 (five) years imprisonment or a heavier sentence after the marriage takes place;

d. One party commits cruelty or serious maltreatment that endangers the other party;

e. One of the parties has a physical disability or illness resulting in not being able to carry out his obligations as husband/wife;

f. Between husband and wife there are constant quarrels and fights and there is no hope of living in harmony again in the household.

The divorce case under the Case Register number: 813 / Pdt.G / 2020 / PA.Mdn filed by the applicant on September 10, 2020 to the Registrar's Office of the Medan Religious Court is a divorce case. In the petition, the petitioner stated that the applicant and the respondent had not been gifted with offspring (children) within the age of their marriage which had been approximately 6 (six) years of development. Besides that, the parents of the respondent often interfere in the household affairs of the applicant and the respondent. and the respondent rarely provides physical and mental support to the applicant.

Divorce is always based on a dispute between husband and wife. This stems from the stance that a dispute between husband and wife occurs because one of the parties wants a divorce, therefore doing something that causes disharmonious family relationships. ${ }^{13}$

Based on the statements of the Petitioner and Respondent as well as witnesses at the trial, it can be found that the Petitioner and Respondent are legal husband and wife and have not been gifted with offspring. The household life of the Petitioner and the Respondent was originally harmonious, but later disputes and quarrels often occur because they have not been gifted with offspring. The offspring who did not attend the Petitioner's and the Respondent's household was the cause of the disputes and quarrels that were revealed in the trial. Because this can be considered as a principle thing. If the household between the Petitioner and the Respondent continues, it is feared that it will bring harm to the Petitioner and the Respondent because the purpose of marriage is not achieved as stated in item 4 letter d General Elucidation of Law Number 1 Year 1974 concerning Marriage. It must also be admitted that children are children and are one of the ornaments of life in the world, apart from lawful assets based on the word of Allah SWT in the Al-Qur'an chapter Al-Kahfi verse 46.

The differences that occur are not fundamental in making decisions by judges because the value of the power of proof of witness testimony is independent. The meaning of the value of the power of free evidence attached to the witness's evidence is that the truth contained in the testimony given by the witness at trial is considered imperfect and nonbinding so that the judge is not obliged to be bound to accept or reject the truth. Thus, the judge is free to fully accept or reject the truth under the legal principles of proof

\footnotetext{
${ }^{13}$ R. Soetojo Prawirohamidjojo dan Asis Safioedin, Hukum Orang dan Keluarga Buku I-Burgerlyk Wetboek, Alumni, Bandung, 1974, p.115.
} 


\section{CONCLUSION}

Every married couple must have their own ways to prevent a divorce from happening. Divorce is always based on quarrels between husband and wife. This is the reason that a dispute between husband and wife occurs because one of the parties wants a divorce, therefore the family relationship is not harmonious

The offspring who do not attend the household is very important, apart from being the successor of the heir, the child is also the goal of a harmonious household, especially if certain tribes or customs require an offspring to be the successor of the family name. In this case, the applicant and the defendant both did not want to adopt a child, so they decided to divorce at the Religious Court Medan.

\section{REFERENCES}

Abdul, Rahman Ghozali. (2010). Fiqih Munakahat, Jakarta: Kencana

Al-Hamdani. (2002). Hukum Perkawinan Islam, Jakarta: Pustaka Amani

Bushar Muhammad. (2006). Pokok-pokok Hukum Adat, Jakarta, PT Pradnya Paramita

Djamaan Nur., Fiqih munakahat. (1993). Semarang : Dina Utama Semarang

Government Regulation Number 9 of 1975 concerning, Implementation of Law Number 1 of 1974 concerning Marriage

http://staffnew.uny.ac.id/upload/132314547/pendidikan/DIKTAT+HUKUM+ADAT.pdf https://www.fimela.com/parenting/read/3762822/4-penyebab-utama-perceraian-menurutpsikologis

M Ali hasan. (2006). pedoman hidup berumah tangga dalam Islam, Jakarta: Siraja Prenada Media Group

RI Law Number 1 Year 1974 Concerning Marriage, Bandung: Citra Umbara, 2007

Sayyid Sabiq., Fiqih Sunnah. (1993). Bandung: PT. Al-Maarif 